\section{Generation and Characterization of Transgenic Plum Lines Expressing gafp-1 with the bul409 Promoter}

\author{
Hetal M. Kalariya and Guido Schnabel ${ }^{1}$ \\ Department of Entomology, Soils, and Plant Sciences, Clemson University, \\ Clemson, SC 29634 \\ Cesar Petri and Ralph Scorza \\ USDA-ARS, Appalachian Fruit Research Station, Kearneysville, WV 25430
}

Additional index words. Prunus, gastrodianin, lectin, oak root rot

\begin{abstract}
The Gastrodia antifungal protein (GAFP-1) is a mannose-binding lectin that can confer increased disease resistance in transgenic tobacco and plum. In all previously generated, transgenic lines, the gene was under the control of the 35SCaMV promoter. In this study, transgenic plum lines were created from seeds derived from open pollination of the cultivar Bluebyrd (BB-OP) with gafp-1 under the control of the polyubiquitin promoter bul409 and evaluated for Phytophthora root rot (PRR) and Root knot nematode (RKN) susceptibility. One of nine transgenic lines synthesizing GAFP-1 exhibited increased tolerance to PRR caused by $P$. cinnamomi. The same line (BB-OP-1) was also significantly more tolerant to RKN infection caused by Meloidogyne incognita. BB-OP-1 was more resistant to PRR and equally resistant to RKN compared with the cultivar Stanley-derived 4J line, which expresses gafp-1 under the control of the 35SCaMV promoter. GAFP-1 synthesis in BB-OP-1 was not elevated by pathogen infection, suggesting that the bul409 promoter is not inducible in the plum/GAFP-1 system. This study confirms the usefulness of the gafp- 1 gene in various cultivars of transgenic plum and establishes that the bul409 promoter is at least equal in effectiveness to the 35SCaMV promoter for gafp-1 expression in transgenic lines of woody plants.
\end{abstract}

South Carolina and Georgia are major peach-producing states in the southern United States. Several soilborne organisms cause significant problems on peach in South Carolina, including PRR and RKN. PRR is a disease with economic impact on the production of peach $(P$. persica) and other Prunus species worldwide mainly as a result of tree mortality (Haygood et al., 1986; Kephart and Dunegan, 1948; Kouyeas, 1971; Stylianides et al., 1985). In the southeastern United States, the disease is primarily caused by P. cinnamomi (Erwin and Ribeiro, 1996). Excessive soil moisture, moderate temperature, and rootstock susceptibility contribute to disease development (Browne and Mircetich, 1996). The soilborne pathogen is difficult to control even with fun-

Received for publication 9 Feb. 2011. Accepted for publication 6 May 2011.

This study was funded in part by USDA-CSREES S-RIPM grant no. 2005-34103-15588 and USDA-CSREES special grant no. 2004-34126-14388 under project number SC-1000642 as well as USDA NRI grant no. 2002-35319-12527 and the South Carolina Peach Council.

Technical contribution number 5892 of the Clemson University Experiment Station.

We thank P. Karen Bryson for technical assistance, Dr. Steven Jeffers for supplying the Phytopththora strain, Dr. Patrick D. Gerard for statistical advice, and Dr. Alexis Nagel for helpful comments on this manuscript during the preparation period.

${ }^{1}$ To whom reprint requests should be addressed; e-mailschnabe@clemson.edu. gicide treatments. Current chemical control options include the application of fosetylaluminum and mefenoxam. Fumigants 1,3dichloropropen and chloropicrin are also recommended for management of soilborne pathogens (Methyl Bromide Technical Options Committee, 1994). The efficiency of fumigants, however, is dependent on environmental factors such as soil type, soil moisture, and soil temperature (Horton et al., 2010).

Crop damage resulting from plant parasitic nematodes is estimated at $\approx \$ 157$ billion worldwide annually (Abad et al., 2008). Among the most devastating nematodes are Meloidogyne species. Members of this genus cause root knot disease and have a host range of more than 2000 plant species (Lamberti, 1979; Sasser, 1977). M. incognita, M. javanica, and $M$. arenaria are the most damaging species in tropical regions (Triantaphyllou, 1985). In the United States, M. incognita is a widespread pathogen of tomatoes, cotton, and soybeans (Castagnone-Sereno, 2006; Ortiz et al., 2010) and one of the most common species reducing fruit production in peach and other stone fruit orchards (Nyczepir et al., 1997). Pre-plant fumigation with 1,3-dichloropropene and metam sodium is still used for RKN control in southeastern peach orchards (Horton et al., 2010), but plants can be killed by 1,3-dichloropropene if planted too soon after fumigation. Control of nematodes is extremely difficult once an orchard is established. An orchard may be in existence for 15 to 25 years.
Creating rootstocks for fruit trees with resistance to fungal root pathogens and nematodes is a desirable component of Integrated Pest Management practices. Classical breeding has in the past been the only method available to develop disease-resistant rootstocks. Progress has been made in the example of the peach rootstocks KID I, PR204, GF305, and GF677, which showed some resistance against Phytophthora cactorum and P. megasperma (Thomidis et al., 2001). Nevertheless, progress has been slow and sources of resistance available for conventional breeding are limited. Genetic engineering offers a complementary method of developing resistance that can greatly expand the pool of resistance genes and offers a way to test these genes in a shorter timeframe.

Genes expressing mannose-binding lectins in monocotyledonous species have been used to generate transgenic plants resistant to a wide range of pathogenic and pest organisms (Peumans and Van Damme, 1995). The Gastrodia anti fungal protein is a mannose-binding lectin with antifungal activity in vitro to Valsa ambiens (Wang et al., 2001) and other fungal pathogens, including Armillaria mellea, Rhizoctonia solani, Gibberella zeae, Ganoderma lucidum, and Botrytis cinerea (Hu and Huang, 1994; Xu et al., 1998). GAFP expression in transgenic cotton increased resistance to $\mathrm{Ver}$ ticillium wilt (Wang et al., 2004) and, in contrast to other lectins, GAFP-1 showed efficacy against RKN and PRR in transgenic line $4 \mathrm{~J}$ derived from open pollination (OP) of the plum cultivar Stanley (Nagel et al., 2008). The gafp-1 gene in line 4J was under the control of the CaMV35S promoter. Furthermore, line $5 \mathrm{D}$, expressing the gafp-1 gene, resulted in the development of fewer eggs and juveniles of ring nematode, $M$. xenoplax (Nyczepir et al., 2009). Although GAFP-1 protein expression in plum showed increased resistance to fungal and non-fungal pathogens (Nagel et al., 2008), higher levels of resistance were desired. The promoter bul409 was shown to be more active in transgenic potato compared with the CaMV35S promoter lines and expression level of beta-glucuronidase (GUS) in transgenic potato plants with the polyubiquitin promoter bul409 was found 30-fold higher when compared with lines with the CaMV35S promoter (Rockhold et al., 2008). The objectives of this study were to generate 'Bluebyrd' plum lines expressing gafp-1 under the control of the bul409 promoter, to confirm GAFP-1 protein expression in transgenic lines, and to determine their susceptibility to $P$. cinnamomi and $M$. incognita relative to the susceptibility of untransformed controls and the previously characterized $4 \mathrm{~J}$ line.

\section{Materials and Methods}

Generation of transgenic plum lines expressing gafp-1 under the control of the bul409 promoter. The gafp-1 gene, under the control of the bul409 promoter and the Ubi3 terminator, was inserted at the multiple cloning site, with HindIII and SacI, of the pBINPLUS/ARS vector (Fig. 1) (Belknap 


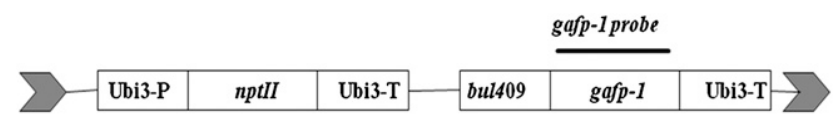

LB

RB

Fig. 1. Schematic diagram of pBINPLUS/ARS vector with insertion of the gafp-1 gene placed under bul409 promoter and Ubi3-T (terminator).

et al., 2008). Agrobacterium tumefaciens strain EHA 105 (Hood et al., 1993) was transformed with the pBINPLUS/ARS-gafp- 1 vector and prepared for infection as described previously (González-Padilla et al., 2003).

For plant transformation, 'Bluebyrd' plum mature seed hypocotyl slices were used as the source of explants. Transgenic plant production was performed using the method described by Petri et al. (2008). Briefly, endocarps were removed and seeds were soaked in a $1 \%$ sodium hypochlorite solution for $30 \mathrm{~min}$ followed by rinsing with sterile distilled water. Epicotyle and radicle were removed and the hypocotyl was sliced into three cross-sections. Media for transformation and shoot regeneration was as described by González-Padilla et al. (2003). Explants were cocultured with A. tumefaciens in shoot regeneration medium (SRM) without antibiotics but supplemented with 2,4-D. After $3 \mathrm{~d}$, explants were transferred to SRM supplemented with $80 \mathrm{mg} \cdot \mathrm{L}^{-1}$ kanamycin and 300 $\mathrm{mg} \cdot \mathrm{L}^{-1}$ timentin. As shoots appeared, explants were transferred to shoot-growing medium containing $80 \mathrm{mg} \cdot \mathrm{L}^{-1}$ kanamycin and $300 \mathrm{mg} \cdot \mathrm{L}^{-1}$ timentin. When shoots elongated to $\approx 1 \mathrm{~cm}$, they were separated from the clusters and placed in rooting medium containing $40 \mathrm{mg} \cdot \mathrm{L}^{-1}$ kanamycin and $300 \mathrm{mg} \cdot \mathrm{L}^{-1}$ timentin. Plantlet acclimatization and establishment in a greenhouse was performed also as described by Petri et al. (2008).

Transgenic lines were derived from seeds from OP of 'Bluebyrd' plum. 'Bluebyrd' plum is self-incompatible; therefore, transgenic lines were half-siblings sharing the same female parent, 'Bluebyrd'. These lines as well as control lines derived from OP of 'Bluebyrd' are referred to in this report as BB-OP. A total of 18 BB-OP transgenic lines, two each of empty vector BB-OP and 'Stanley' OP control lines and five each of wild type BB-OP and 'Stanley' control lines were used for comparison with the previously characterized 4J plum line included in this study (Nagel et al., 2008). In this line, the gafp-1 gene is driven by the CaMV35S promoter instead of the bul409 promoter.

Determination of gafp-1 gene copy numbers in transgenic plum lines. DNA was isolated from young and fully expanded leaves of transformed and non-transformed BB-OP lines as described previously (Kobayashi et al., 1998). Briefly, 10 to $15 \mu \mathrm{g}$ DNA was digested with BamHI (New England Biolabs, Ipswich, MA), separated on a $1 \%(\mathrm{w} / \mathrm{v})$ agarose gel, and blotted to a positively charged nylon membrane (Roche Diagnostics Corporation, Indianapolis, IN). The membrane was hybridized with a Digoxigenin-11-dUTP alkali- labile (Roche Diagnostics Corporation) -labeled probe coding for gafp- 1 cDNA. The probe was generated by polymerase chain reaction using gafp-1-specific primers (Wang et al., 2001).

Detection of Gastrodia antifungal protein-1 protein in transgenic plum lines. Gastrodia antifungal protein (anticipated size $12 \mathrm{kDa}$ ) was detected using immunoblot analysis from root tissue of transformed and non-transformed plum lines from 9-monthold trees as described previously (Nagel et al., 2010). Line 4J (positive control) and a randomly selected 'Stanley' empty-vector control line (negative control) were included as references (Nagel et al., 2008). Briefly, total protein was extracted from root tissue of transformed and non-transformed plum plants using TRI reagent ${ }^{\circledR}$ (Sigma-Aldrich, St. Louis, MO). Total protein $(20 \mu \mathrm{g})$ was used to perform sodium dodecyl sulfatepolyacrylamide gel electrophoresis using $15 \%$ Tris- $\mathrm{HCl}$ ready Gels (Bio-Rad Laboratories, Hercules, CA). Protein was transferred to an immunoblot polyvinylidene fluoride membrane (Bio-Rad Laboratories), and immunoblotting was performed using rabbit anti-GAFP-1 polyclonal antisera developed by Zymed ${ }^{\circledR}$ Laboratories and goat antirabbit alkaline phosphatase conjugated antibodies (Promega Corp., Madison, WI). Band detection was accomplished using a solution of BCIP/NBT tablet. This experiment was performed twice for each transgenic, empty vector, and wild-type control line. Results were reproducible and were combined. Expression of GAFP-1 was scored visually relative to the expression of GAFP- 1 in the 4J line: equal to $(+++)$, up to $50 \%$ less $(++)$, and less than $50 \%(+)$.

Selection and propagation of transgenic plum lines. Transgenic lines revealing a strong, consistent GAFP-1 protein signal on immunoblots were used for further experiments. The performance of BB-OP lines was compared with previously characterized line 4J expressing GAFP under the CaMV35S promoter (Nagel et al., 2008). BB-OP-0 and 'Stanley' empty vector and untransformed lines were included as negative controls. Vegetative propagation of the plant material was carried out in a biosafety Level 2 greenhouse under constant temperature $\left(27 \pm 5{ }^{\circ} \mathrm{C}\right)$ and light conditions (16/8 h day/night). Original transformed lines (T0 lines) were pruned every 4 weeks to stimulate shoot growth. Shoots $(15$ to $20 \mathrm{~cm})$ were pruned off the T0 lines, gently scraped at the cut end, and dipped into "ROOTECH" Original Cloning Gel (Technaflora Plant Product Ltd., Port Coquitlam, B.C., Canada). Shoots were placed 3 to $4 \mathrm{~cm}$ deep in sterile vermiculite in 36 -well plastic trays $(25 \times$ $50 \mathrm{~cm}$ ) and covered with a lid to prevent dehydration. Plants were misted and watered daily and fertilized once per week. Fungicide applications (Pristine 0.019\% a.i.; BASF, Research Triangle Park, NC) were applied with a mister as needed to control fungal colonization of emerging leaves as a result of the humid condition during propagation.

Disease susceptibility screening. 'Bluebyrd' lines BB-OP-1, BB-OP-3, BB-OP-17, BB-OP-18, BB-OP-21, BB-OP-8 EV, nontransformed lines BB-OP-0, BB-OP-30, BB-OP-31, 'Stanley' 4J, and 'Stanley' untransformed controls were investigated for susceptibility to PRR as described previously (Nagel et al., 2008). P. cinnamomi isolate $05-1127$ was obtained from naturally infected peach and had been used for similar studies (Nagel et al., 2008). Briefly, $P$. cinnamomi was grown on PARP selective medium in the dark at $22{ }^{\circ} \mathrm{C}$ for $3 \mathrm{~d}$. Agar plugs $(6 \mathrm{~mm})$ with actively growing mycelium were added to $500-\mathrm{mL}$ Erlenmeyer flasks containing $300 \mathrm{~mL}$ of a sterile, V8-juice:vermiculite $(1: 2 \mathrm{v} / \mathrm{v})$ mixture. The flasks were incubated in the dark at $22{ }^{\circ} \mathrm{C}$ for 8 weeks.

Experimental plum lines were transplanted to $5-\mathrm{cm}$ diameter plastic torpedo pots containing $\approx 400 \mathrm{~cm}^{3}$ sterile potting soil mixed with $2 \%$ of the infested or non-infested V8-juice:vermiculite. Pots were suspended in plastic racks (10 pots per rack) and placed in 10 -gallon plastic bins. For error control, all treatments were arranged in a randomized complete block design. Plants were watered as needed and after 1 week were flooded for $48 \mathrm{~h}$ to promote infection. Disease symptoms were evaluated every other day. Shoot symptoms were rated as: $0=$ healthy plant, $1=$ less than $25 \%$ of the plant showing chlorosis and necrosis, $2=25 \%$ to $50 \%$ of the plant showing chlorosis and necrosis, $3=50 \%$ to $75 \%$ of the plant showing chlorosis and necrosis, and $4=$ greater than $75 \%$ of the plant exhibiting chlorosis and necrosis (Fig. 2 ). The experiment was concluded after $30 \mathrm{~d}$, when the majority of inoculated control plants had severe wilting. Random root pieces were sampled from inoculated seedlings, surface-sterilized, and plated on PARPH [PARP + $50 \mathrm{mg}$ 5-methylisoxazol3-ol (hymexazol)] selective medium (Jeffers, 2006) to confirm the presence of $P$. cinnamomi. The disease severity score was calculated as described previously (Nagel et al., 2008). The entire experiment was performed twice with three replicates per experiment.

Three-month-old plants of line BB-OP-1, 4J, 'Stanley' untransformed control, and BBOP-0 untransformed control were used to assess susceptibility to $M$. incognita as described previously (Nagel et al., 2008). Briefly, plum plants were transplanted into $20-\mathrm{cm}$ diameter plastic pots containing 1000 $\mathrm{cm}^{3}$ of sterile sand:vermiculite $(1: 1 \mathrm{vol} / \mathrm{vol})$. Root-knot nematode egg inoculum was extracted from infected tomato roots (cv. Rutgers) using a $10 \% \mathrm{NaOCl}$ solution diluted in tap water. Twelve-week-old plum plants were inoculated with 6000 eggs per pot by 


\section{Score 0}

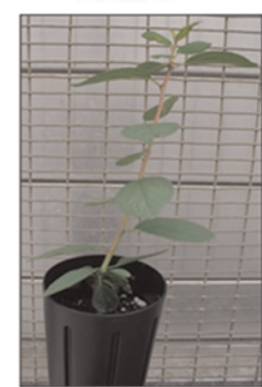

Score 1

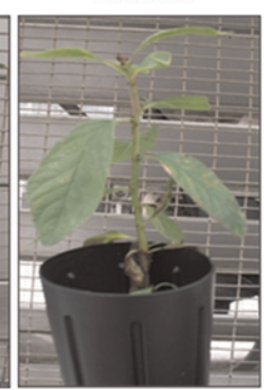

Score 2

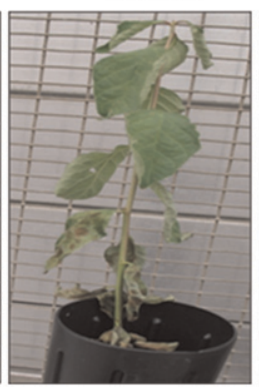

Score 3

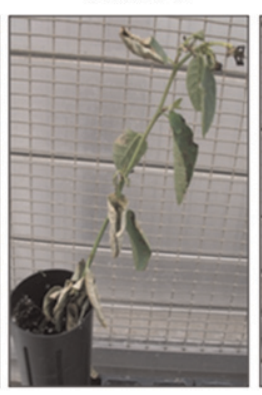

Score 4

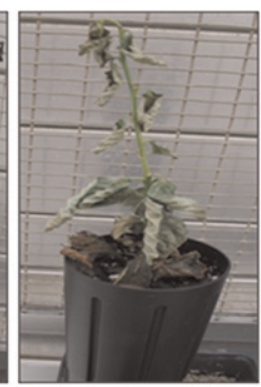

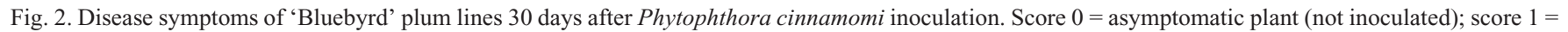
less than $25 \%$ wilted; score $2=25 \%$ to $50 \%$ wilted; score $3=$ more than $50 \%$ to $75 \%$ wilted; score $4=$ more than $75 \%$ wilted.

Table 1. Number of gafp-1 copies and GAFP-1 protein expression in roots of plum lines used in this study.

\begin{tabular}{|c|c|c|c|}
\hline Plum line & Transformation status ${ }^{2}$ & gafp-1 gene copy no. & $\begin{array}{l}\text { Relative GAFP protein } \\
\text { expression in roots }\end{array}$ \\
\hline$\overline{\mathrm{BB}-\mathrm{OP}-1}$ & Transformed & 2 & ++ \\
\hline BB-OP-2 & Transformed & 2 & + \\
\hline BB-OP-3 & Transformed & 4 & +++ \\
\hline BB-OP-4 & Transformed & 0 & - \\
\hline BB-OP-5 & Transformed & 5 & - \\
\hline BB-OP-6 & Transformed & 1 & - \\
\hline BB-OP-7 EV & Empty vector & 0 & - \\
\hline BB-OP-8 EV & Empty vector & 0 & - \\
\hline BB-OP-10 & Transformed & 5 & + \\
\hline BB-OP-13 & Transformed & 2 & + \\
\hline BB-OP-14 & Transformed & 1 & - \\
\hline BB-OP-15 & Transformed & 3 & - \\
\hline BB-OP-17 & Transformed & 4 & ++ \\
\hline BB-OP-18 & Transformed & 2 & ++ \\
\hline BB-OP-19 & Transformed & 2 & + \\
\hline BB-OP-21 & Transformed & 4 & ++ \\
\hline BB-OP-23 & Transformed & 2 & - \\
\hline BB-OP-27 & Transformed & 2 & - \\
\hline BB-OP-28 & Transformed & 2 & - \\
\hline BB-OP-29 & Transformed & 2 & - \\
\hline BB-OP-30 & Untransformed & 0 & - \\
\hline BB-OP-31 & Untransformed & 0 & - \\
\hline BB-OP-32 & Untransformed & 0 & - \\
\hline BB-OP-33 & Untransformed & 0 & - \\
\hline BB-OP-0 & Untransformed & 0 & - \\
\hline Stanley control & Untransformed & 0 & - \\
\hline Stanley 4J & Transformed & 2 & +++ \\
\hline
\end{tabular}

${ }^{\mathrm{z}}$ Expression of GAFP-1 was measured and scored being equal (+++), up to $50 \%$ less (++), and less than $50 \%(+)$ relative to the expression in the 'Stanley' $4 \mathrm{~J}$ line.

GAFP-1 = Gastrodia antifungal protein; BB-OP = open-pollinated 'Bluebyrd'.

creating three holes $(\approx 1 \mathrm{~cm}$ deep $)$ in the medium around the base of each plant and pipetting $2 \mathrm{~mL}(1000$ eggs $/ \mathrm{mL})$ into each of the three holes. Negative control plants received tap water. For error control, all treatments were arranged in a randomized complete block design. The study was ended $60 \mathrm{~d}$ after inoculation and the number of egg masses per root system, number of eggs per root system, and fresh root weight were determined. BB-OP-1 was selected for the RKN assay out of five BB-OP transgenic lines used for the PRR assay based on its low disease severity score in PRR assays compared with other transgenic lines. After weighing the roots, they were stained using a $20 \%(\mathrm{v} / \mathrm{v})$ solution of McCormick Schilling red food color (Thies et al., 2002) for $25 \mathrm{~min}$, after which the roots were rinsed with tap water and blotted dry. Egg masses were observed under $\times 20$ magnification. The number of galls and egg masses was determined per plant and normalized using root fresh weight to calculate the numbers per gram fresh root weight. $M$. incognita populations were originally isolated from infected peach in Georgia. The experiment was performed twice with five replicates.

Gastrodia antifungal protein -1 synthesis in roots of transgenic lines before and after inoculation. To determine whether the bul409 promoter is pathogen-inducible, total protein was extracted as described from roots of BBOP-1 $1 \mathrm{~d}$ before and $5 \mathrm{~d}$ after inoculation with $P$. cinnamomi and $1 \mathrm{~d}$ before and $30 \mathrm{~d}$ after inoculation with $M$. incognita. Immunoblot analysis was conducted as described previously.

Statistical analysis. Bartlett's test for homogeneity of variances was performed for repeated experiments. Data sets with homogeneous variances were combined and ana- lyzed for significant differences between each line. In regard to the ordinal Phytophthora disease rating values, a non-parametric comparison using the chi-square test revealed no differences between treatments compared with the means calculated with the parametric method. Thus, for simplicity, we show means and SE bars of the parametric analysis. Values were analyzed using the general linear model or analysis of variance and least significant difference mean separation procedures of SAS (Version 9.2; SAS Institute, Cary, NC).

\section{Results}

A total of 18 plum lines were obtained from gafp-1 transformation of individual BB-OP seeds and 17 tested positive for the presence of gafp-1. In addition, five non-transformed plants from seeds of 'Bluebyrd' (BB-OP-0, BB-OP-30, BB-OP-31, BB-OP-32, and BB$\mathrm{OP}-33)$ and two transgenic empty vector control lines (BB-OP-7 EV and BB-OP-8 $\mathrm{EV})$ were included in this study (Table 1). BB-OP lines were not phenotypically different from each other or from the non-transformed or empty vector control lines based on visual assessment of shoot length, leaf shape, size, and color (data not shown).

Southern hybridization showed a range of copy numbers from zero to five inserts (Table 1 ). Only nine of the $18 \mathrm{BB}-\mathrm{OP}$ lines revealed a GAFP-1 signal. The consistently strongest signals (data from at least two independent experiments) were found for lines BB-OP-1, $-3,-17,-18$, and -21 (Table 1; Fig. 3A-B). No GAFP-1 signal was detected in either the empty vector controls or the non-transformed control lines. Based on more than four different immunoblot assays, the GAFP-1 signal strength of BB-OP-3, which exhibited consistently one of the highest GAFP-1 signals, was comparable in intensity to line $4 \mathrm{~J}$.

The five lines with the highest GAFP-1 signals (BB-OP-1, -3, -17, -18, and -21) were selected for PRR disease tests based on their GAFP-1 expression. Included were also one empty vector line (BB-OP-8 EV) and several untransformed control lines BB-OP-0, BB$\mathrm{OP}-30$, and BB-OP-31 to sample the natural half-sibling genetic variation in disease susceptibility. The results of two independent experiments were not significantly different $(P=0.3044, \alpha=0.05)$ and the data sets were 
combined. BB-OP-1 was significantly more resistant to PRR disease compared with other BB-OP lines and compared with the control lines (Fig. 4). None of the other transgenic BB-OP lines were statistically different from the BB-OP control lines. In addition, disease severity of line $4 \mathrm{~J}$ was numerically but not significantly different from the 'Stanley' control line ( $P=0.3088$, at $\alpha=0.05$; Fig. 4). BB-OP-3 showed strong GAFP expression, comparable to $4 \mathrm{~J}$ expression, and demonstrated similar resistance in PRR disease tests. BB-OP-1 was statistically better for PRR disease control compared with $4 \mathrm{~J}$ at the $\alpha=0.1$ level (data not shown).

Based on the PRR test results, the best performing BB-OP line (BB-OP-1) was subjected to RKN disease screening tests and compared with BB-OP-0 untransformed control, 'Stanley' untransformed control, and line 4J. BB-OP-0 was chosen as the sole control line because it represented an average level of susceptibility to PRR among BB-OP control lines. Between the independent experiments, no statistical differences were found $(P=$ 0.6687 for eggs $/ \mathrm{g}$ of root; $P=0.5145$ for egg mass $/ \mathrm{g}$ of root; and $P=0.6154$ at $\alpha=0.05$ ) for galls/g of root; thus, the combined data set is shown. For all parameters tested (eggs/g of root, egg mass/g of root, and galls/g of root), line BB-OP-1 as well as $4 \mathrm{~J}$ performed significantly better than the corresponding controls (Fig. 5). No statistical differences were found between the two transgenic lines $4 \mathrm{~J}$ and BBOP-1 $(P=0.2782$ for eggs $/ \mathrm{g}$ of root; $P=$ 0.8221 for egg mass/g of root; $P=0.3377$ at $\alpha=0.05$ for galls/g of root; Fig. 5).

The inducibility of gafp- 1 after pathogen exposure was estimated using immunoblot analysis. The signals for GAFP-1 in immunoblot analyses were not noticeably higher in root tissue of line BB-OP-1 $5 \mathrm{~d}$ after inoculation with $P$. cinnamomi (Fig. 6A) compared with the non-inoculated BB-OP-1 root tissue. Likewise, no elevated GAFP-1 signal was detected in root tissue $30 \mathrm{~d}$ after inoculation with M. incognita (Fig. 6B) compared with the non-inoculated root tissue.

\section{Discussion}

Among 17 BB-OP lines that tested positive for the presence of gafp-1 DNA, only nine were found to express the GAFP-1 protein in immunoblot studies. The failure of some transgenic plant lines to produce heterologous protein despite successful insertion of the target gene has been described before in other systems, including transgenic potato using the potato leafroll virus replicase transgene (Ehrenfeld et al., 2004) and transgenic walnut using the crylA(c) gene (Dandekar et al., 1998). In addition, variation in the level of transgene expression is common among transformed plants. It is not completely understood why inserted transgenes do not function in some transgenic plants, but it is possible that the insertion of the transgene into the plant genome occurs at locations that do not support gene expression. Kumar and Fladung (2001) showed that AT-rich regions in the genome of transgenic aspen (Populus) may be involved in the defense against foreign gene insertions. In studies of transgenic tobacco and tomato, ATTTA sequences and A+T-rich regions affected the protein expression level in plants (Perlak et al., 1991). Another possible explanation is that mutations in the promoter or the gafp-1 gene occurred during transformation.

Line BB-OP-1 showed significantly less severe disease symptoms in PRR and RKN tests, although it did not exhibit the highest GAFP-1 synthesis level among transgenic lines. Although BB-OP-3 had a greater number of copies of the gafp-1 gene compared with BB-OP-1 and expressed higher levels of GAFP, it was more susceptible than BB-OP1 to $P$. cinnamomi. Similarly, transgenic $A$. thaliana lines with high levels of disease resistance did not correspond to the ones with the highest expression of the insecticidal lectin GNA (Galanthus nivalis agglutinin) in roots (Ripoll et al., 2003) Expression of GAFP-1 in transgenic plum line 5D was higher than that of lines $4 \mathrm{~J}$ and $4 \mathrm{I}$, but $5 \mathrm{D}$ was more susceptible in PRR and RKN disease tests (Nagel et al., 2008). It is possible that the multiple insertions of gafp- 1 copies in many of the BB-OP lines had an effect on the physiology of the plant that may have impaired inherent disease resistance, counteracting the antimicrobial effect of elevated GAFP-1 levels. In immunoblot analyses, proteins with higher molecular weight compared with GAFP-1 (12 kDa) reacted with our GAFP-1 probe. The additional bands were observed in both transgenic and control plants and likely signaled nonspecific binding of the polyclonal antibody. Similar nonspecific binding has been observed in previous studies on tobacco (Cox et al., 2006) and plum (Nagel et al., 2008). Nonspecific binding of a polyclonal antibody is not uncommon, as shown for apple shoot-extracted Vfa1 and Vfa2 proteins (Malnoy et al., 2008).

BB-OP-1 displayed resistance against $\mathrm{RKN}$, but its performance in the PRR experiment was not superior to the 'Stanley'-derived $4 \mathrm{~J}$ line. Both lines had reduced numbers of galls, egg masses, and eggs compared with inoculated control lines, effects that had previously been noted for the $4 \mathrm{~J}$ line (Nagel et al., 2008). The gafp-1-expressing lines except BB-OP-1 and BB-OP-3 under the control of bul409 did not result in less disease when compared with the lines with the CaMV35S promoter. Polyubiquitin promoters such as the bul409 have shown enhanced expression of the reporter gene (GUS) in various transgenic plants such as transgenic potato (Rockhold et al., 2008) and rice ( $\mathrm{Lu}$ et al., 2008). The performance of the bul409 promoter may be dependent on the host plant. For example, the polyubiquitin promoter GUBQ1 did not elevate the expression of the GUS reporter gene compared with the CaMV35S promoter in gladiolus, tobacco, rose, rice, and the floral monocot freesia (Joung and Kamo, 2006). In transgenic wheat, the expression of the insecticidal lectin GNA under control of an ubiquitin promoter was significantly lower compared with its expression in transgenic rice (Stoeger et al., 1999).

The bul409 promoter had been shown to be wound-inducible in transgenic potato lines (Rockhold et al., 2008). Expression of bul409

A

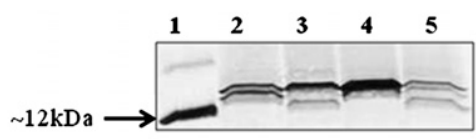

B

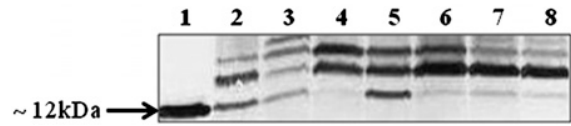

Fig. 3. Immunoblot analysis of total protein extracts $(20 \mu \mathrm{g})$ from root tissue; (A) Lane 1: purified GAFP-1 ( $\approx 12 \mathrm{kDa})$; Lanes 2 and 4: nontransformed 'Stanley' control and BB-OP, respectively; Lanes 3 and 5: transgenic 4J ('Stanley' plum seedling) and BB-OP-3 ('Bluebyrd' plum seedling) lines, respectively. (B) Lane 1: GAFP-1 ( $\approx 12 \mathrm{kDa})$; Lane $2: 4 \mathrm{~J}$ and Lanes 3 to 8: transgenic 'Bluebyrd' plum lines BB-OP-1, BB-OP-2, BB-OP-3, BB-OP-17, BB-OP-18, and BB-OP21, respectively. GAFP-1 = Gastrodia antifungal protein; BB-OP = open-pollinated 'Bluebyrd'.

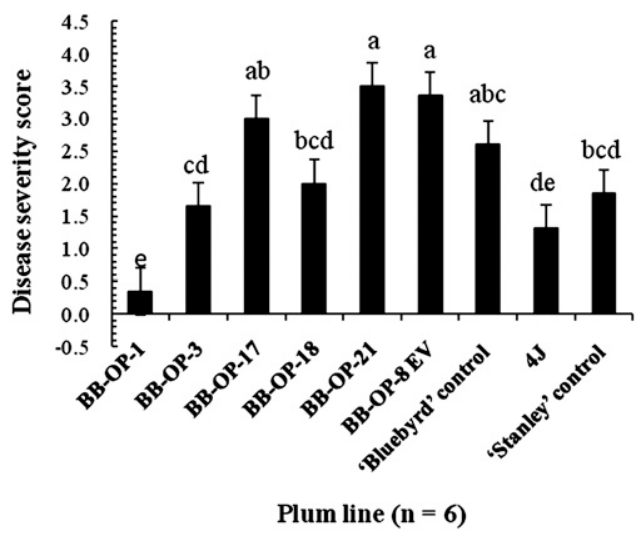

Fig. 4. Disease severity of 3-month-old plum lines BB-OP-1, BB-OP-3, BB-OP-17, BB-OP-18, BB-OP21, BB-OP-8 EV, 'Bluebyrd' control (mixture of lines BB-OP-0, BB-OP-30, and BB-OP-31), 4J, and 'Stanley' control $30 \mathrm{~d}$ after inoculation with Phytophthora cinnamomi. Bars represent the average of two experiments with three replicates each. Bars with the same letter are not significantly different $(\alpha=0.05)$. BB-OP $=$ open-pollinated 'Bluebyrd'. 


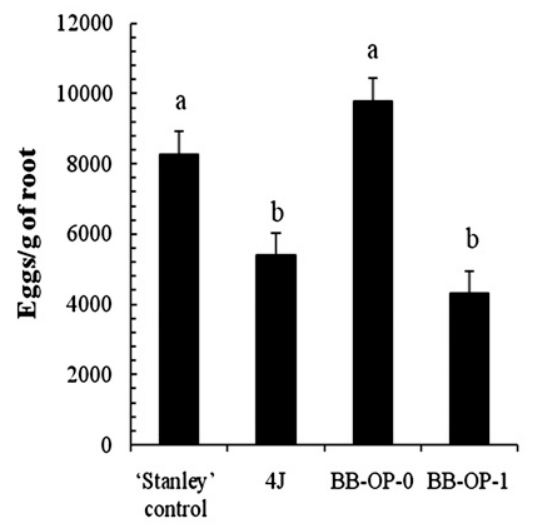

Plum line $(\mathbf{n}=\mathbf{1 0})$
A

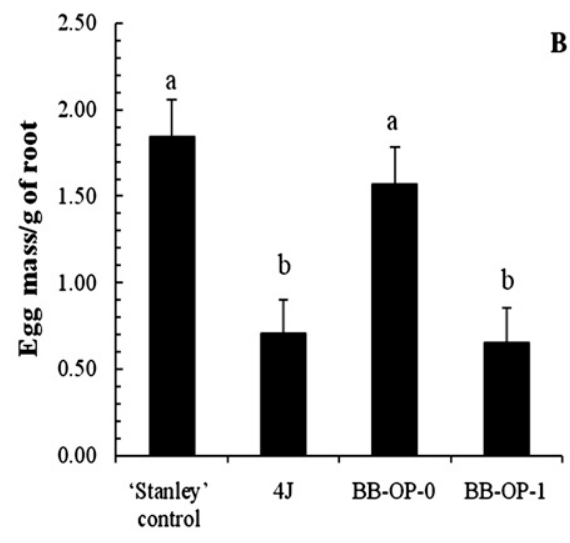

Plum line $(\mathbf{n}=10)$

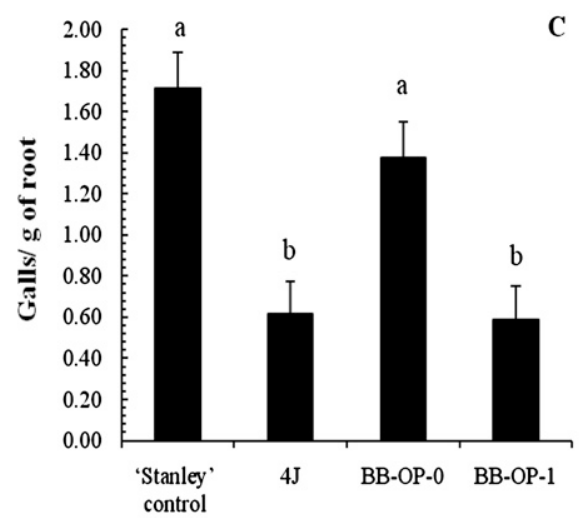

Plum line $(\mathbf{n}=10)$

Fig. 5. Reproduction of Meloidogyne incognita on roots of 'Stanley' control line, 'Bluebyrd' control line (BB-OP-0), transgenic lines 4J, and BB-OP-1. (A) Number of eggs per gram of root; (B) egg mass (egg mass per gram of fresh root); and $(\mathbf{C})$ gall formation (galls per gram of root). Shown is the combined data set of two independent experiments. Bars represent the average of two experiments with five replicates each. Bars with the same letter are not significantly different $(\alpha=0.05)$. BB-OP $=$ openpollinated 'Bluebyrd'.

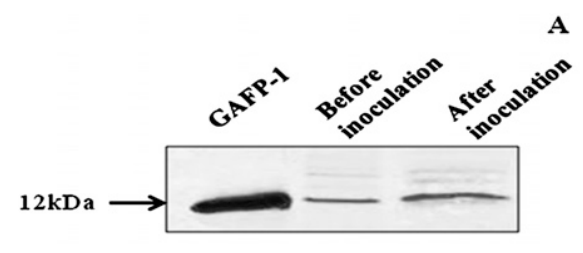

B

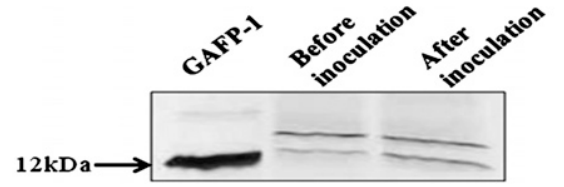

Fig. 6. Immunoblot analysis showing GAFP-1 in 20 $\mu \mathrm{g}$ of total protein from root tissue of transgenic line BB-OP-1 (A) before (Lane 2) and $5 \mathrm{~d}$ after (Lane 3) inoculation with Phytophthora cinnamomi and (B) before (Lane 2) and $30 \mathrm{~d}$ after (Lane 3) inoculation with Meloidogyne incognita. GAFP-1 = Gastrodia antifungal protein; $\mathrm{BB}-\mathrm{OP}=$ open-pollinated 'Bluebyrd'.

promoter-driven GUS mRNA levels was higher in wounded tubers and leaves (Rockhold et al., 2008). Inducibility was not demonstrated in our study. Neither inoculation with $P$. cinnamomi
B

with the earlier study. Stability of GAFP-1 synthesis was also confirmed in transgenic tobacco lines, which were generated in 2004 (Cox et al., 2006) and had been used for GAFP-1 isolation continuously until 2010 (Nagel et al., 2010). The present study confirms the potential for gafp-1 as a disease resistance gene in woody plants. Increased disease resistance has now been demonstrated in two different sources of plum germplasm, 'Stanley' and 'Bluebyrd'. The long-term stability of GAFP-1 synthesis in transgenic plum lines was also confirmed. The suitability of ubiquitin promoter bul 409 for gafp-1 expression plum was established and for BB-OP-1, a relatively high level of resistance to PRR (at $\alpha=0.1$, data not shown) was observed that was comparable to the level achieved in transgenic line $4 \mathrm{~J}$ in which the gafp-1 gene was under the 35SCaMV promoter. In conclusion, this study confirms the usefulness of the gafp-1 gene in various cultivars of transgenic plum and establishes that the bul409 promoter is at least equal in effectiveness to the $35 \mathrm{SCaMV}$ promoter for gafp-1 expression in transgenic lines of woody plants.

\section{Literature Cited}

Abad, P., J. Gouzy, J.M. Aury, P. Castagnone-Sereno, E.G. Danchin, E. Deleury, L. Perfus-Barbeoch, V. Anthouard, F. Artiguenave, V.C. Blok, M.C. Caillaud, P.M. Coutinho, C. Dasilva, F. De Luca, F. Deau, M. Esquibet, T. Flutre, J.V. Goldstone, N. Hamamouch, T. Hewezi, O. Jaillon, C. Jubin, P. Leonetti, M. Magliano, T.R. Maier, G.V. Markov, P. McVeigh, G. Pesole, J. Poulain, M. Robinson-Rechavi, E. Sallet, B. Segurens, D. Steinbach, T. Tytgat, E. Ugarte, C. van Ghelder, P. Veronico, T.J. Baum, M. Blaxter, T. BleveZacheo, E.L. Davis, J.J. Ewbank, B. Favery, E. Grenier, B. Henrissat, J.T. Jones, V. Laudet, A.G. Maule, H. Quesneville, M.N. Rosso, T. Schiex, G. Smant, J. Weissenbach, and P. Wincker. 2008. Genome sequence of the metazoan plant-parasitic nematode Meloidogyne incognita. Nat. Biotechnol. 26:909-915.

Belknap, W., D. Rockhold, and K. McCue. 2008. pBINPLUS/ARS: An improved plant transformation vector based on pBINPLUS. Biotechniques 44:753-756.

Browne, G.T. and S.M. Mircetich. 1996. Effects of month of inoculation on severity of disease caused by Phytophthora species in apple root, crowns and excised shoots. Phytopathology 86:290-294.

Castagnone-Sereno, P. 2006. Genetic variability and adaptive evolution in parthenogenetic rootknot nematodes. Heredity 96:282-289.

Cox, K., D. Layne, R. Scorza, and G. Schnabel. 2006. Gastrodia anti-fungal protein from the orchid Gastrodia elata confers disease resistance to root pathogens in transgenic tobacco. Planta 224:1373-1383.

Dandekar, M., G. McGranahan, P. Vail, S. Uratsu, C. Leslie, and J. Tebbets. 1998. High levels of expression of full-length $c r y 1 \mathrm{~A}(\mathrm{c})$ gene from Bacillus thuringiensis in transgenic somatic walnut embryos. Plant Sci. 131:181-193.

Ehrenfeld, N., E. Romano, C. Serrano, and P. ArceJohnson. 2004. Replicase mediated resistance against potato leafroll virus in potato Desirée plants. Biol. Res. 37:71-82.

Erwin, D. and O. Ribeiro. 1996. Isolation and detection of Phytophthora, p. 8-41. In: Erwin, D. and O. Ribeiro (eds.). Phytophthora disease world wide. APS Press, St. Paul, MN. 
González-Padilla, M., K. Webb, and R. Scorza. 2003. Early antibiotic selection and efficient rooting and acclimatization improve the production of transgenic plum plants (Prunus domestica L.). Plant Cell Rep. 22:38-45.

Haygood, R.A., C.H. Graves, and W.H. Ridings. 1986. Phytophthora root rot and stem canker of peach trees in Mississippi. Plant Dis. 70:866868.

Hood, E., S. Gelvin, L. Melchers, and A. Hoekema. 1993. New Agrobacterium helper plasmids for gene transfer to plants. Transgenic Res. 2:208218 .

Horton, D., P. Brannen, B. Bellinger, and D. Ritchie. 2010. Southeastern peach, nectarine and plum pest management and culture guide. Univ. of Georgia Coop. Ext. Serv. Bull. \#1171. 17 Oct. 2010. <http://www.ent.uga.edu/peach/ PeachGuide.pdf $>$.

$\mathrm{Hu}, \mathrm{Z}$. and Q.Z. Huang. 1994. Induction and accumulation of the antifungal protein in Gastrodia elata. Acta Bot. Yunnanica 16:169-177.

Jeffers, S. 2006. Identifying species of Phytophthora. Clemson University. 17 Nov. 2010. $<$ http://fhm.fs.fed.us/sp/sod/misc/culturing_ species_phytophthora.pdf $>$.

Joung, Y. and K. Kamo. 2006. Expression of a polyubiquitin promoter isolated from Gladiolus. Plant Cell Rep. 25:1081-1088.

Kephart, J.E. and J.C. Dunegan. 1948. Infection of seedling peach stems by zoospores of Phytophthora cactorum. Phytopathology 38:580-581.

Kobayashi, N., T. Horikoshi, H. Katsuyama, T. Handa, and K. Takayanagi. 1998. A simple and efficient DNA extraction method for plants, especially woody plants. Plant Tissue Cult. Biotechnol. 4:76-80.

Kouyeas, H. 1971. On the apoplexy of fruit trees caused by Phytophthora species. Ann. Inst. Phytopath. Benaki N.S. 10:163-170.

Kumar, S. and M. Fladung. 2001. Gene stability in transgenic aspen (Populus). II. Molecular characterization of variable expression of transgene in wild and hybrid aspen. Planta 213: 731-740.

Lamberti, F. 1979. Economic importance of Meloidogyne species in subtropical and mediterranean climates, p. 342-357. In: Lamberti, F. and C.E. Taylor (eds.). Root-knot nematodes (Meloidogyne species): Systematic, biology and control. Academic Press, New York, NY.

Lu, J., E. Sivamani, X. Li, and R. Qu. 2008. Activity of the $5^{\prime}$ regulatory regions of the rice polyubiquitin rubi3 gene in transgenic rice plants as analyzed by both GUS and GFP reporter genes. Plant Cell Rep. 27:1587-1600.

Maleck, K. and R. Dietrich. 1999. Defense on multiple fronts: How do plants cope with diverse enemies? Trends Plant Sci. 4:215-219.

Malnoy, M., M. Xu, E. Borejsza-Wysocka, S. Korban, and H. Aldwinckle. 2008. Two receptor-like genes, Vfal and Vfa2, confer resistance to the fungal pathogen Venturia inaequalis inciting apple scab disease. Mol. Plant Microbe Interact. 21:448-458.

Methyl Bromide Technical Options Committee. 1994. Montreal protocol on substances that deplete the ozone layer. 19 Oct. 2010. <http:// www.unep.org/ozone/teap/Reports/MBTOC/ MBTOC94.pdf>.

Nagel, A., H. Kalariya, and G. Schnabel. 2010. The gastrodia antifungal protein (GAFP-1) and its transcript are absent from scions of chimericgrafted plum. HortScience 45:188-192.

Nagel, A.K., R. Scorza, C. Petri, and G. Schnabel. 2008. Generation and characterization of transgenic plum lines expressing the gastrodia-anti fungal protein. HortScience 43:1514-1521.

Nyczepir, A., A.K. Nagel, and G. Schnabel. 2009. Host status of three transgenic plum lines to Mesocriconema xenoplax. HortScience 44:19321935.

Nyczepir, A.P., R.W. Miller, and T.G. Beckman. 1997. Root-knot nematodes on peach in the southeastern United States: An update and advances. Afr. Plant Prot. 3:115.

Ortiz, B.V., C. Perry, P. Goovaerts, G. Vellidis, and D. Sullivan. 2010. Geostatistical modeling of the spatial variability and risk areas of southern root-knot nematodes in relation to soil properties. Geoderma 156:243-252.

Perlak, F., R. Fuches, D. Dean, S. McPhersont, and D. Fischhoff. 1991. Modification of the coding sequence enhances plant expression of insect control protein genes. Proc. Natl. Acad. Sci. USA 88:3324-3328.

Petri, C., K. Webb, J.M. Hily, C. Dardick, and R. Scorza. 2008. High transformation efficiency in plum (Prunus domestica L.): A new tool for functional genomics studies in Prunus species. Mol. Breed. 22:581-591.

Peumans, W.J. and E.J.M. Van Damme. 1995. Lectins as plant defense proteins. Plant Physiol. 109:347-352.

Ripoll, C., B. Favery, P. Lecomte, E. Van Damme, W. Peumans, P. Abad, and L. Jouanin. 2003.
Evaluation of the ability of lectin from snowdrop (Galanthus nivalis) to protect plants against root-knot nematodes. Plant Sci. 164: 517-523.

Rockhold, D., S. Chang, N. Taylor, P.V. Allen, K. McCue, and W. Belknap. 2008. Structure of two Solanum bulbocastanum polyubiquitin genes and expression of their promoters in transgenic potatoes. Amer. J. Potato Res. $85: 219-226$.

Sasser, J.N. 1977. Worldwide dissemination and importance of the root-knot nematodes Meloidogyne species. J. Nematol. 22:585-589.

Stoeger, E., S. Williams, P. Christou, R. Down, and J. Gatehouse. 1999. Expression of the insecticidal lectin from the snowdrop (Galanthus nivalis agglutinin; GNA) in transgenic wheat plants: Effect on predation by the grain aphid Sitobion avenae. Mol. Breed. 5:65-73.

Stylianides, D.C., A. Chitzanidis, and I. TheochariAthanasiou. 1985. Evaluation of resistance to Phytophthora species Rhizoctonia solani in stone fruit rootstocks. Options Mediterraneennes, CIHEAM. 85:73-78.

Thies, J., S. Merrill, and E. Corley. 2002. Red food coloring stain: New, safer procedures for staining nematodes in roots and egg masses on root surfaces. J. Nematol. 34:179-181.

Thomidis, T., J. Cullum, K. Elena, and S. Jeffers. 2001. Relative resistance of four peach rootstocks to Phytophthora cactorum and P. megasperma. J. Phytopathol. 149:599-604.

Triantaphyllou, A.C. 1985. Cytogenetics, cytotaxonomy and phylogeny of root-knot nematodes, p. 113-126. In: Sasser, J.N. and C.C. Carter (eds.). An advanced treatise on Meloidogyne. North Carolina State University Graphics, Raleigh, NC.

Wang, X., G. Bauw, E. Van Damme, W. Peumans, Z. Chen, M. Van Montagu, G. Angenon, and W. Dillen. 2001. Gastrodianin-like mannosebinding proteins: A novel class of plant proteins with antifungal properties. Plant J. 25: 651-661.

Wang, Y., D. Chen, D. Wang, Q. Huang, Z. Yao, F. Liu, X. Wei, R. Li, Z. Zhang, and Y. Sunday. 2004. Over-expression of Gastrodia antifungal protein enhances Verticillium wilt resistance in coloured cotton. Plant Breed. 123:454-459.

Xu, Q., Y. Liu, X. Wang, H. Gu, and Z. Chen. 1998. Purification and characterization of a novel anti-fungal protein from Gastrodia elata. Plant Physiol. Biochem. 36:899-905. 